\title{
COVID-19 Pandemics in Uganda led to Cessation of the Comprehensive HIV Program in Rural Areas of North Lake Victoria Region
}

\section{B. Silharova (Barbara Silharova)1, 2, M. Holubcik (Marian Holubcik)1, 2, V. Krcmery (Vladimir Krcmery)1,2, J. Suvada (Jose Suvada) 1, 2}

${ }^{1}$ St. John Paul II Clinic, Health Initiative Associates and St. Elizabeth

University Tropical, Slovakia.

${ }^{2}$ Slovak Medical University SZU, Tropical Diseases Program Buikwe, Uganda.

\section{E-mail address:}

barbora.silharova@gmail.com

\section{Reprint address:}

Barbora Silharova

Health Initiatives Association, Clinic Jan Pavol II. Buikwe

Uganda

Source: Clinical Social Work and Health Intervention

Pages: $26-27$
Volume: 12

Cited references: 2
Issue: 1

\section{Reviewers:}

Daria Kimuli

Catholic university of Eastern Africa, Nairobi, KE.

Jarmila Holkova

Malindi

\section{Keywords:}

Covid 19. HIV.

\section{Publisher:}

International Society of Applied Preventive Medicine i-gap

CSWHI 2021; 12(1): 26 - 27; DOI: 10.22359/cswhi_12_1_06 (C) Clinical Social Work and Health Intervention

\section{Abstract:}

15 years of sustainable activity in Buikwe and the rural area in Lugazi Province Republic of Uganda has led to a substantial decrease of HIV. However, this disease is still, together with malaria, the most important public health problem in the North Lake Victoria region. Unfortunately, arrival of Covid-19 led to a temporary decrease of outreach activity due to decreased mobility and restrictions. Therefore, the HIV epidemic may spread just due to the secondary effect of another epidemic diseases. 


\section{Introduction}

HIV Malaria and TB still are major killers among diseases in Sub-Saharan Africa. However, the arrival of Covid-19 may have an adverse effect on control of those three major public health problems due to funds consumed instead of e.g. HIV for Covid disease. In addition also non-communicable diseases such as hypertension, diabetes etc. are emerging events in rural Africa. 15 years of sustainable activity in Buik a rural area in Lugazi Province Republic of Uganda has led to a substantial decrease of HIV. However, this disease is still, together with malaria, the most important public health problem in North Lake Victoria region. Unfortunately, arrival of Covid19 led to temporary decrease of outreach activity due to decreased mobility and restrictions, therefore the HIV epidemic may spread just due to secondary effect of another epidemic diseases.

\section{Patients and Methods}

The capacity of the St. John Paul II Clinic of Health associates with an initiative HIA powered by the St. Elizabeth University Tropical Diseases Program serves two Outpatient Departments: with one for chronic diseases; one for incoming outpatients; both serving approximately 540 and 500 patients per month.

In addition, an anti-malnutrition program is active for 30 supports a month and TB therapy is included in comprehensive health services as well.

Four preventive programs in health care within the last year including spiritual assistance monthly is complemented by a social program for 579 households with 1,969 children.

Another 691 families received financial assistance or social support including of 625 those who received school support or educational support within the community.

\section{Results and discussion}

Spectrum of non-communicable and communicable diseases in Outpatient Departments serving approximately 500 patients monthly included the following diagnoses:

- sickle cell anemia $11 \%$

- hypertension plus diabetes about $4 \%$

- isolated diabetes $4 \%$

- isolated hypertension 5\%

- respiratory tract infections about $30 \%$
- malaria $10 \%$

- gastroenteritis $15 \%$

Twice monthly HIV outreaches have been performed for 10 years leading to a decrease of HIV prevalence and also TB sporadicity, however since the Covid-19 alert in Uganda, this service has to be stopped.

\section{Conclusions}

A disease pandemic may adversely affect other diseases crucial for public health status in Sub- Saharan Africa such as screening for malaria, TB and HIV. Because the Covid-19 prevalence in rural African areas is lower than in the USA and Europe, hopefully the screening programs will be reopened to continue the everlasting battle against HIV, TB and other tropical diseases.

\section{References}

1. MASAN J, SRAMKA M, SABO A, KALATOVA D, ROTTERMUND J, RUZICKY E (2020) The covid-19 disease situation prior to October 2020 in selected countries: the potentially severe consequences of Covid-19 on the nervous system and several key solutions to Covid-19 in relation to digitization and artificial intelligence. In: Acta Misiologica / Bucko Ladislav . - ISBN 2453-7160. - Vol. 14, no. 2 p. 112-126.

2. PERI H A, SUBRAMANIAN S, SLADECKOVA V, BYDZOVSKY J, DURCOVA B, KUBALIKOVA Z, OLAH M, MATULNIKOVA L, DOKTOROV A, BERESOVAA, KUBIK F, FULA M, OTRUBOVA J, KALATOVA D, KUKUCKOVA E, JURINOVA S, BENCA J, SHAHUM A, HOY LEANG HOINAND CHENG HOIN, SETA S/ Early detection of adverse therapy reaction in orphan children with AIDS (short communication) / In: Acta Missiologica. - ISSN 13377515. - Vol. 13, no. 2 (2019) p. 184-187. 